\title{
性周期に伴う䧳ヒツジの排尿行動とそれに対する \\ 雄ヒッジの匂い嗅ぎ行動
}

\author{
小田切 敬子
}

(財)平岡環境科学研究所, 川崎市 215

(1996 年 10 月 2 日受理)

\section{緒言}

繁殖期における雌ヒツジの排尿行動は, 雌自身 の性的許容状態を雄に伝える重要な役割を果たし ている。そして, 雄は雌の尿の匂いを嗅ぐことに よって雌の発情の度合を確かめていると考えられ る。匂い嗅ぎ行動には, 鼻つけ行動とフレーメン の 2 種類があるが，このうち尿に対して多く発現 する行動として, フレーメンがよく知られてい る。雄ヒツジのフレーメンの発現頻度は, 雌の性 周期に伴って変動し, 発情期に最も高頻度に発現 する1)。しかしながら, BLISSIT ら ${ }^{2,3)}$ は, 雄ヒッジ は必ずしもフレーメンによって雌の発情期と非発 情期の尿を区別しているとは限らないと論じた。 一方, 雌の排尿行動は発情期に頻発するといわれ てきだ)。しかしながら，䧳ヒッジの排尿行動は 発情期よりもむしろ非発情期に多く発現するとい う報告5) ああり，未だ不明確である。そこで，本研 究では性周期に伴う雌ヒツジの排尿回数と雌の尿 に対する雄の匂い嗅ぎ行動の発現回数について観 察をした。さらに実験的研究として, 雌の尿の噴 霧に対する雄の反応を調べた。

\section{材料および方法}

\section{(1) 行動観察}

(1) 供試ヒツジおよび飼養管理

コリデール系の雑種雄 2 頭 (年齢 ; 2,7 才, 体 重; $56,90 \mathrm{~kg}$ ) と雌 5 頭（年齢；2４才，体重; $27 \sim 42 \mathrm{~kg}$ ）を用いた。飼育は, 一隅にシェルター
が設置してある屋外パドック $(4 \times 8 \mathrm{~m})$ において 行った。飼料は NRC 飼養標準 ${ }^{6)}$ に準拠して，生 草, ヘイキューブおよび濃厚飼料を 1 日 2 回与 え，水および固型塩は自由摂取できるようにし た。夜間照明 $(40 \mathrm{w})$ は 60 ルクスを基準に自動点 灯および消灯するように蛍光灯を設置した。

(2) 行動の記録と解析

雌雄をペアリングさせ，5組についての行動を 観察した。期間はそれぞれ，1994 年 8 月 20〜9月 1 日， 9 月 3 日 9 月 17 日， 9 月 25 日 10 月 10 日, 10 月 17 日〜 11 月 3 日, 11 月 4 日〜 11 月 18 日であった。ペアリングは, 血中プロジェステロ ンの定性判定によって雌の黄体期初期を確認して から開始した ${ }^{7,8)}$ 。雌の発情が終わって黄体期が回 帰するまでのすべての行動をビデオ撮影し，䧳の 排尿行動, 雄の乗駕行動, 鼻つけ行動, フレーメ ン行動について記録した。䧳ヒツジが腰を低く下 げる姿勢を排尿行動とみなした。

乗駕行動が初めて発現した日を 0 日とし，-9 日から 5 日まで, 上記の 4 行動について解析し た。 -9 日から 5 日までの行動の回数を 24 時間ご とに集計した。そして，5ペアについてのそれ ぞれの発現回数を平均した。また, 雌の排尿行動, 雄の鼻つけ行動およびフレーメン行動の性周期に 伴う変動については一要因の分散分析を行った。 また，性周期に伴う上記 3 行動の発現回数につい ては, 対応のある平均值の差の検定を行った。

(2) 尿に対する反応試験

(1) 供試ヒツジおよび飼養管理

Jpn. J. Sheep Sci., 33 : 11-16. 1996

The relationship between a ram's sniffing and a ewe's urinating behavior during estrous cycle.

Keiko ODAGIRI

The Hiraoka Environmental Science Laboratory, Kawasaki-shi 215 
採尿には, 前述の行動観察期間中にペアリング を行った雌ヒッジ 5 頭を使用した。これらの尿に 対する反応試験にはコリデール系雑種雄ヒツジ （1〜7才） 9 頭を使用した。雄ヒッジは行動観察の ためのパドックから視覚的および嗅覚的情報を遮 断された実験場（ビニールハウス， $5 \times 3.5 \times 15 \mathrm{~m}$, 色; 緑) に拈いて飼育された。NRC 飼養標準に準 拠して生草, ヘイキューブおよび濃厚飼料を 1 日 2 回与えた。水は常置した。

(2) 反応試験とフレーメン判定

ペアリング期間中, 毎日雌ヒッジの尿を採取し た。午前 6 時に雌ヒッジの外陰部下方にプラス チックケースを装着し, 排尿時にケースの中に尿 が入る方法で採取した。プラスチックケースは午 前 7 時に回収した。

採取した尿（10〜25cc）は速やかに小型噴霧器 に入れ替え $(2 \sim 3 \mathrm{cc})$, 雄ヒッジの鼻孔に 2 3 回 噴霧して反応試験を行った。そして, 噴霧直後に フレーメンが起こうたかどうかを記録した。判定 は一, 土, +の 3 段階とした。噴霧時に, 無反応 の場合は一, 少し口をあけて鼻をかすかに震わせ た場合は土，頸をのばして上唇を大きく巻上げ, 明らかなフレーメン反応を示した場合を十と判定 した（Fig. 1)。 -9 日から8日までについてのフ レーメン判定について集計した。

結果

\section{(1) 行動観察}

性周期に伴う雌の排尿, 雄の乗駕, フレーメン, 鼻つけ行動の変動を Fig. 2 に示した。乗駕行動は 0 日から 2 日の 3 日間発現し，0日に全体の 50\%, 1 日に $48 \%$ 発現した。排尿回数は性周期に伴って
有意に変動した $[\mathrm{F}(14,60)=1.86, \mathrm{P}<0.01]$ 。ま た, 排尿回数は -1 日から急激に増加し始め, 0 日に おいて他のよ゙の日よりあ有意に多く発現した( $\mathrm{t}$ 検 定 : $\mathrm{p}<0.05)$ 。その後, 1 日には排尿回数は急激に 減少し, 2 日以降は -2 日以前の回数に戻った。

尿に対するフレーメンは雌の排尿回数之同様の 発現パターンを示し, -1 日から増加し，0日に最 あ多く発現した。そして, 排尿回数之同様に 1 日 には減少し, その後, 低值を示した。雌ヒッジの 性周期に伴う排尿と雄のフレーメン回数との間に は有意な正の相関関係が認められた（ $\mathrm{r}=0.98, \mathrm{p}$ <0.001)。また，排尿行動に対してフレーメンが 発現する割合は，観察期間を通して平均 37\%（29 〜 47\%)であった。

尿に対する鼻つけ行動の回数は, -1 日（平均

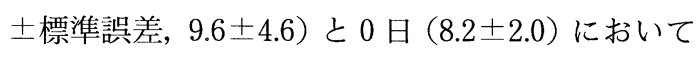

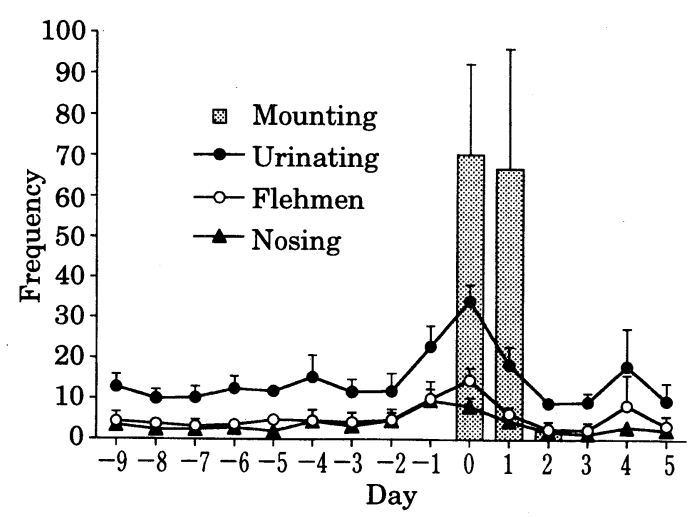

Fig. 2. Relationship between mounting, urinating and sniffing behavior. Sniffing behavior was divided between flehmen and nosing. Column bar represents S.E.

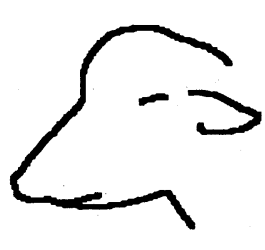

$-$

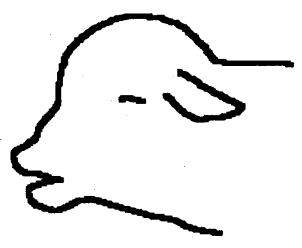

$\pm$

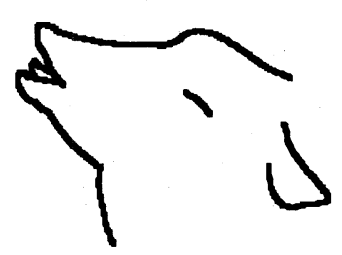

$+$

Fig. 1. Qualitative judgments of flehmen response.

$-:$ Flehmen doesn't occur. \pm : Lips open a little.

$+:$ Lips curl to contact the nostril. 
多く発現する傾向が見られた。また，排尿回数に 対する鼻つけ行動の割合は, -1 日 $(42 \%)$ におい て他の日 (平均 24\%) よりあ高い傾向がみられ た。性周期に伴う鼻つけの発現回数はフレーメン より有意に少なかった（ $\mathrm{p}<0.005) 。 ま た ， 2$ 者の 発現回数の間には有意な正の相関関係が認められ た $(\mathrm{r}=0.84, \mathrm{p}<0.001)$ 。雌の排尿行動と雄の鼻つ け行動との間にも同様に有意な正の相関関係が認 められた $(\mathrm{r}=0.89, \mathrm{p}<0.001)$ 。

(2) 反応試験

5 頭の雌の尿に対する 9 頭（No. 1 No. 9）の 雄のフレーメン反応の結果を Table 1 に示した。 性周期を発情休止期, 発情前期, 発情期とに分け, それぞれのステージで発現するフレーメン反応に

Table 1. Frequency and \% of donor rams' flehmen responses on three estrus stages

\begin{tabular}{|c|c|c|c|c|}
\hline & $(\overline{\%})$ & $\frac{ \pm}{(\%)}$ & $\stackrel{+}{+}(\%)$ & Total \\
\hline Anestrus & $\begin{array}{l}232 \\
(59)\end{array}$ & $\begin{array}{l}16 \\
(4)\end{array}$ & $\begin{array}{l}148 \\
(37)\end{array}$ & 396 \\
\hline Pro-estrus & $\begin{array}{r}19 \\
(53)\end{array}$ & $\begin{array}{c}4 \\
(11)\end{array}$ & $\begin{array}{r}13 \\
(36)\end{array}$ & 36 \\
\hline Estrus & $\begin{array}{r}61 \\
(59)\end{array}$ & $\begin{array}{c}8 \\
(8)\end{array}$ & $\begin{array}{r}35 \\
(33)\end{array}$ & 104 \\
\hline
\end{tabular}

anestrus : day -9 to day -2 and day 3 to day 5 , pro-estrus : day -1 , estrus : day 0 to day 2
ついて一， 土，十の 3 段階評価を行った結果，こ れら 3 段階の発現割合はそれぞれどのステージ間 においても差は認められなかった。また， 3 種類 のどの発情ステージにおいても, 約 40\%（41〜 47\%）の割合でフレーメン反応（土，＋）が認め られた。

次に， 5 頭の雌ヒツジの尿に対する 9 頭の雄そ れぞれにおけるフレーメン反応の発現回数と割合 を調べた（Table 2)。最む年齢の高いNo. 1 が最 屯高い割合で十反応を示した。フレーメンの一反 応が $50 \%$ 以上だった個体はNo. 2 (5才), No. 3 (3才), No.4 (2才) およびNo.8（1才）であっ た。また，士反応の発現は少なく，9頭における土 反応の発現割合は平均 $6 \%$ であった。また, No. 3 (3才), No.8（1才）およびNo.9（1才）の個体 は土反応を全く示さなかった。

\section{考察}

本研究においては, 個体の行動を持続的に追跡 する連続記録法を用いた ${ }^{9)}$ 。そして，5頭の雌のそ れぞれの性周期におけるすべての行動を記録し, 24 時間ごとに集計した。その結果，5頭の雌ヒッ ジにおいて発情前日から頻尿となり, 発情初日に 排尿回数は最む多くなることが明らかとなった。 従って, 雌の排尿回数は性周期を把握するための 指標になると考えられた。しかしながら，BLAND and JUBILAN ${ }^{10)}$ は, 雌ヒッジの排尿回数は発情初 日に最も少なくなると報告した。また, STEVENS

Table 2. Number and $\%$ of nine rams' flehmen responses

\begin{tabular}{|c|c|c|c|c|c|c|c|c|}
\hline \multirow{2}{*}{ Ram. No. } & \multirow{2}{*}{$\begin{array}{l}\text { Age } \\
\text { (year) }\end{array}$} & \multicolumn{7}{|c|}{$\begin{array}{l}\text { Judgements } \\
\pm\end{array}$} \\
\hline & & Times & $\%$ & Times & $\%$ & Times & $\%$ & Total \\
\hline No. 1 & 7 & 13 & 24 & 3 & 6 & 38 & 70 & 54 \\
\hline No. 2 & 5 & 20 & 71 & 1 & 4 & 7 & 25 & 28 \\
\hline No. 3 & 3 & 68 & 87 & 0 & 0 & 10 & 13 & 78 \\
\hline No. 4 & 2 & 67 & 79 & 2 & 2 & 16 & 19 & 85 \\
\hline No. 5 & 2 & 40 & 49 & 6 & 7 & 36 & 44 & 82 \\
\hline No. 6 & 2 & 26 & 37 & 4 & 6 & 40 & 57 & 70 \\
\hline No. 7 & 1 & 30 & 38 & 16 & 21 & 32 & 41 & 78 \\
\hline No. 8 & 1 & 35 & 69 & 0 & 0 & 16 & 31 & 51 \\
\hline No. 9 & 1 & 4 & 40 & 0 & 0 & 6 & 60 & 10 \\
\hline Total & - & 303 & 57 & 32 & 6 & 201 & 38 & 536 \\
\hline
\end{tabular}


$ら^{5)}$ は，非発情の雌ヒツジは発情中の雌ヒッジょ りも頻回に排尿すると報告した。これらの研究 は, 発情前日から頻尿となり, 発情初日に排尿回 数は最む多くなった我々の研究結果とは異なっ た。これは，我々の観察方法が連続記録法を用い た長時間の観察であるのに対して，彼らの研究方 法は観察時間が 5 分間と短かったり, 性周期に伴 う個体毎の排尿回数を調べたものではなかったた めと考えられた。排尿行動における個体差や日内 変動を考慮して，記録は個体別に長期間にわたっ て持続的にとることが必須であると考えられる。

また，雌ヒツジの排尿回数と雄ヒッジのフレー メンの発現回数の変動には密接な関係が認めら れ，性周期を通して排尿行動の約 37\% に対して フレーメンが発現した。また，雌ヒッジの排尿回 数が発情初日にピークを示すことから, 雌ヒッジ はコミュニケーションの媒体として尿を利用し， 排尿行動によって自らの繁殖に係わる生理的情報 を雄に提供していると考えられた。そして，雄は 雌からのメッセージを匂い嗅ぎ行動によって常に 一定の割合で受け取っていると考えられる。

また, 雌ヒッジから視覚的および嗅覚的に隔離 された 9 頭の雄による雌の尿に対する反応試験に おいて，フレーメン反応 $(+;$ 土）は非発情期か ら発情期にわたってほぼ一定の割合 (平均 43\%) で発現した。これは，前述の性周期にともなうフ レーメンの観察における発現割合 $(37 \%)$ と差は認 められなかった。これらのことより, 雄のフレー メン行動は雌の性周期のステージに関係なく常に 一定の割合で起こっていることが示唆された。

また，本研究においてはフレーメンの発現と年 齢との間には関連はみられず，若い雄よりあ成熟 した雄の方が頻度高くフレーメン行動を示すとい う VICTOR ${ }^{11}$ の研究とは異なった。もし，フレーメ ンが雌の発情を認知する役割をもっているのであ るならば，雄の繁殖戦略としては若い個体より成 熟した雄においてフレーメンを頻回に行うことが 有利であると考えられる。しかしながら，フレー メン行動の役割が単に尿の匂いを嗅ぐだけである のならば，鋤鼻器が正確に機能する個体は年齢に 関係なくフレーメンが発現することは予想され る。実際に DONCHIN ら ${ }^{12)}$ は 1 週令未満のヒツジ にフレーメン行動を誘発させている。
フレーメン行動は鋤鼻器への匂いの取り込みを 助長したり，さらに鼻口蓋管を通って口腔内に匂 いを取り込む役割を果たしていると言われてい

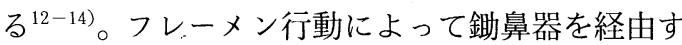
る匂い情報は副嗅球で中継された後，脳の認識中 枢ではなく本能的な行動を支配している視床下部 へ送られる。この嗅覚経路を副嗅覚系という ${ }^{15)}$ 。

他方, 鼻腔粘膜の嗅上皮で受容される匂いは， 主嗅球で中継されて大脳辺縁系に送られ，より判 断力を伴う反応を引き起こす。この嗅覚経路を主 嗅覚系という ${ }^{15)}$ 。このように, 嗅覚系には副嗅覚 系と主嗅覚系の 2 種類が存在し，それぞれお互い に機能を分担している ${ }^{16-19)}$ 。

マウスにおける匂いの識別能は主嗅覚系が無傷 であれば，鋤鼻器あるいは副嗅球を破壊しても阻 害されないといわれている ${ }^{14,20,21)}$ 。また，ヒッジ においても発情と非発情の識別は主嗅覚系によっ てなされているとBLISSITT ら ${ }^{3)}$ は論じた。

本研究におけるフレーメンの発現割合は, 雌の 排尿回数に相関しており, 雌の発情ステージに よって変動しなかった。一方，鼻つけは雌の排尿 回数と相関はしたものの, 発情前日に最も多く発 現し，発情が開始すると減少する傾向がみられ た。これは，発情開始前には雄ヒッジが雌の発情 を知るために尿を頻回に嗅ぎ，尿中の匂いの変化 を調べていると考えられる。発情が開始すると鼻 つけが減少したのは，雄が一旦発情を確認したの ならば，あはや頻回に尿の匂いをかぐ必要がない からであろう。つまり発情と非発情の匂いの区別 はフレーメンによって行われるのではなく，鼻つ け行動によって行われると考えられる。あし, 鼻 つけ行動が主嗅覚系由来の行動であるならば，上 記の考えは雄ヒツジがフレーメンによって発情之 非発情の尿を区別しないという BLISSITT ら³)の意 見を支持する。

今後は，フレーメンおよび鼻つけが発現してい る時の嗅覚神経細胞の変化, あるいは, 副嗅覚系 あるいは主嗅覚系を阻害した時の行動の観察と いった実験的研究が必要となるであろう。

\section{要 約}

性周期に伴う雌ヒツジの排尿回数と，その尿に 対する雄ヒッジの匂い嗅ぎ行動および乗駕行動と 
の関係について検討した。乗駕行動が発現した初 日を 0 日とし， -9 日から 5 日までの雌雄の行動 を全てVTR で録画し，これらについて連続記録 法で解析した。その結果，雌ヒッジの排尿はー1 日から増加し，0日に他のよ゙の日よりも有意に多 く発現した $(\mathrm{P}<0.05)$ 。フレーメンは排尿と同様 の発現パターンを示し, 雌の尿に対して一定の割 合 $(37 \%)$ で発現した。一方，鼻つけの発現回数 はフレーメンおよび排尿回数と有意な正の相関 $(\mathrm{p}<0.001)$ を示したが，発現のピークはー1日で あった。次に，行動観察期間中に採取された雌の 尿を, 雌ヒッジから隔離された雄に人為的に噴霧 した時のフレーメン反応について調べた。その結 果, 発情期と非発情期の雌の尿に対する雄のフ レーメンの発現割合には差は認められなかった。

以上より，雌ヒッジの排尿行動は性周期を把握 する指標となることが示唆された。また，フレー メンは雌の尿を常に一定の割合で探査しており, 発情期と非発情期の識別は鼻つけによって行われ ていることが示唆された。

\section{謝辞}

本研究は茨城大学においてなされたものです。 研究支援をしていただきました茨城大学・増殖管 理学研究室, 松沢安夫教授ならびに柘野通子氏, 北川哲也氏, 藤谷明憲氏ら学生諸氏に対して深謝 いたします。

\section{文献}

1) Odagiri, K., H. Marumo, Y. Matsuzawa and $Y$. YoSHIKAWA, Changes in serum progesterone concentration in ewes and mounting and sniffing behaviour in rams during ewes' oestrous cycle. J. Ethol. 1996. (in press)

2) Blissit, M.J., K.P. Bland and D.F. Cottrell, Discrimination between the odours of fresh oestrus and non-oestrus ewe urine by rams. Appl. Anim. Behav. Sci., 25 : 51-59.1990 a.

3) Blissitt, M.J., K.P. Bland and D.F. COTTRELL, Olfactory and vomeronasal chemoreception and the discrimination of oestrus and non-oestrus ewe urine odours by the ram. Appl. Anim. Behav. Sci., 27 : 325-335.1990 b.

4) HART, B.J., The behavior of domestic animals.
W.H. Freeman and company, New York. 1985. （森 裕司 訳, Dr. ハートの動物行動学入門, 千 クサン出版社. 1995)

5) Stevens, K., G.C. Perry and S.E. Long, Effect of ewe urine and vaginal secretions on ram investigative behaviour. J. Chem. Ecol., $8: 23-$ 29.1982 .

6）吉本 正 監修 (出岡謙太郎訳), NRC 飼養標準, めん羊, 日本緬羊研究会. 1991 .

7）小田切敬子・丸茂契子・松沢安夫 ・山海 直・吉 田高志, プロジェステロン定性測定用キットによ る雌羊の性周期判定. 日本緬羊研究会誌. $31: 1$ 4, 1994.

8) Odagiri, K. and H. Marumo, Estrus diagnosis in ewes by using a plasma/serum progesterone enzyme immunoassay (EIA) kit. Anim. Sci. Technol. (Jpn), 67 : 713-718. 1996.

9）小田切敬子・松沢安夫, 子七ッジの遊び行動にお ける瞬間サンプリング法の適用の検討. 動物心理 学研究. 43:9-16. 1993.

10) Bland, K.P. and B.M. Jubilan, Correlation of flehmen by male sheep with female behaviour and oestrus. Anim. Behav., 35 : 735-738.1987.

11) VICTOR, R. Flehmen, mounting and copulation among members of a semi-wild cattle herd. Anim. Behav., 31 : 641-650. 1983.

12) Donchin, G.W., G.W. De Vane and D. CATON, Metkephamid-induced flehmen in lambs. Physiol. Behav., 33 : 335-337. 1983.

13) Melese-D'Hospital, P.Y. and B.L. Hart, Vomeronasal organ cannulation in male goats : evidence for transport of fluid from oral cavity to vomeronasal organ during flehmen. Physiol. Behav., 35 : 941-944. 1985.

14) Ladewig, J. and B.L. Hart. Flehmen and vomeronasal organ function in male goats. Physiol. Behav., 24 : 1067-1071. 1980.

15) Meredith, M., Pheromones and Reproduction in Mammals. (Vandenbergh, J.G. ed.), pp 199252, Academic Press, 1983.

16) Keverne, E.B. Olfaction and taste-dual systems for sensory processing. Trends Neurosci., $1: 32-34.1978$ a.

17) Hradecky, P., R.F. Sis and W.R. Klemm, Distribution of flehmen reactions of the bull throughout the bovine estrous cycle. 
Theriogenology, $20: 197-207.1983$.

18) Keverne, E.B. Olfactory cues in mammalian sexual behaviour. In Biological Determinations of Sexual Behaviour (Hutchinson, J. ed.). pp. 723-763. John Wiley Chichester, 1978 b.

19）椛 秀人 - 瀬戸勝男, 㫐いの記憶と生殖内分泌, 日本生理学雑誌，53:151-168. 1991.

20) Lomas, D.E. and E.B. Keverne, The role of the vomeronasal organ and prolaction in the acceleration of puberty in female mice. J. Reprod. Fert., 66 : 101-107. 1982.

21) Reynold, J. and E.B. Keverne, The accessory olfactory system and its role in the pheromonally medated suppression of oestrus in grouped mice. J. Reprod. Fert., $57: 31-35$. 1979.

\section{Summary}

Relationship between the frequency of a ewe's urination and the sniffing and mounting behavior of a ram during estrous cycle was examined. The first day on which mounting behavior occurred was standardized as day 0 . All ewe and ram behavior was recorded from day -9 to day 5 and analyzed. The frequency of urination increased from day -1 , and on day 0 it occurred more than on any other day $(\mathrm{p}<0.05)$. The frequency of flehmen showed the same pattern of urinating, and that of flehmen to ewe's urine occurred at a constancy rate (37\%). On the other hand, though the number of nosings correlated with those of flehmen and urinating, the peak occurred on day -1 . And also, a ewe's urine was sprayed artificially towards rams isolated from ewes and rams' flehmen responses were investigated. As a result, there were no significant differences between the rate of a ram's flehmen to a ewe's estrous urine and that of non-estrous urine. These results were demonstrated that ewe's urinating behavior became the index of the estrous cycle. Furthermore, it was suggested that flehmen behavior have a function to monitor ewes' urine constantly during estrous cycle. 